\title{
Development of an inexpensive functional textile product by applying accounting cost benefit analysis
}

\author{
DOI: 10.35530/IT.071.01.1692
}

SOBIA NASEEM
GAO LEI FU
MUHAMMAD MOHSIN
MUHAMMAD SOHAIL AUNJAM

\author{
MUHAMMAD ZEESHAN RAFIQ \\ KHALID JAMIL \\ SHAZIA SALAMAT
}

\section{ABSTRACT - REZUMAT}

\section{Development of an inexpensive functional textile product by applying accounting cost benefit analysis}

This research is to utilize accounting cost benefit analysis for manufacturing of economically cost-effective cut resistant gloves knitted from core spun yarns made up of nylon and polyester with E-glass as core. E-glass has a significant impact on the cut resistance and abrasion resistance of the gloves. The gloves are knitted by using core spun yarns, and tested for their physical, cut \& abrasion resistant properties. Economic characteristics of final product are critically observed and analysed through cost benefit analysis. Results elaborate that Polyester/E-glass hand gloves have special mechanical properties like Abrasion resistance and Blade cut resistance. Instead, Nylon/E-glass hand gloves have good air permeability. Cost benefit analysis reveal that the outcomes are comparable to functional requirements within low cost.

Keywords: cost benefit analysis, gloves cut resistance, abrasion resistance, core spun yarn

\section{Dezvoltarea unui produs textil funcțional convenabil prin aplicarea analizei cost-beneficiu}

Acest studiu are ca scop utilizarea analizei cost-beneficiu pentru fabricarea mănușilor rezistente la tăiere, convenabile din punct de vedere economic, tricotate din fire filate din nailon și din poliester cu miez din E-glass. E-glass are un impact semnificativ asupra rezistenței la tăiere și a rezistenței la frecare a mănușilor. Mănușile sunt tricotate folosind fire filate cu miez și sunt testate pentru proprietățile lor fizice, precum rezistența la tăiere și rezistența la frecare. Caracteristicile economice ale produsului final sunt observate și analizate în mod critic, prin analiza cost-beneficiu. Rezultatele arată faptul că mănușile din poliester cu miez E-glass prezintă proprietăți mecanice, precum rezistența la frecare și rezistența la tăiere. În schimb, mănușile din nailon cu miez E-glass prezintă permeabilitate la aer ridicată. Analiza cost-beneficiu relevă faptul că rezultatele sunt comparabile cu cerințele funcționale, păstrând costurile reduse.

Cuvinte-cheie: analiza cost-beneficiu, rezistența la tăiere a mănușilor, rezistența la frecare, fir filat cu miez

\section{INTRODUCTION}

Individuals employed in high mechanical risk areas are bare to hurts and leads to major harm to human life, machinery and material. Principally, hands and arms face most of the hazards, which stimulated development of protected gloves and sleeves. Protective gloves manufactured from HDPE and Nylon blended yarns are the superlative but expensive [1].

The cost benefit analysis estimates the overall values of a proposed project and then evaluates its effectiveness that how a much a project is beneficial in terms of cost and generate maximum revenue [2]. It may be calculated as:

$$
N P V=(1+r)^{t}
$$

$N P V$ is the net present value.

There is no unravelling problem in steel core yarns which offer better cut and abrasion resistance, but steel is a metal which conducts heat and electricity and limits there use in controlled conductive conditions [3].

Leather and wire mesh steel gloves are being manufactured from many years providing protection but are not comfortable to wear. Invention of high-performance fibers and polymers made room for manufacturing of engineered fabrics for protection competing with conventional materials [4].

The need of time is to build a product with protection, comfort and low cots all in one. Fiber structures, yarn structures and mechanical properties of fiber are the most dominant aspects to shape goods for protection against clean \& sharp edge cuts [5].

Cut resistance is the ability of material to withstand impairment when challenged with a moving sharpedge object. The total energy obligatory to proliferate a cut majorly subject to the coefficient of friction among the cutting edge and the material [6].

Protection against cut can be enhanced by increasing material weight of constituent materials, using high performance materials or by means of composite 
yarns in various blends of stainless steel, fiberglass and synthetic yarns. Weight is directly proportional to flexibility, affecting hand fatigue. Finishes and coatings can be applied on the outer surface of gloves to enhance grip on slipping surfaces [7-8].

High performance polyethylene filament, HPPE staple fibers, fiberglass, stainless steel, polyester, polyamide and cotton are being used to produce composite yarns for cut resistant textile products. The ultimate objective is to meet the cut resistance values as per European standard EN388 (1994) [9].

E-glass in blend with Polyester or Nylon composite yarns doesn't have many applications in this area. Such combinations have not been studied before and now this research gap will be filled through this study by combining high performance properties of glass fiber along with some normal filaments like polyester and nylon for cost benefits and flexural properties in final product [10].

Composite yarns or core spun yarns are comprised of two elements; the core, which is most of the time a synthetic monofilament yarn surrounded by the second constituent, a staple fiber sheath [11].

The core component gets zero to low twist level and promises to provide high strength of the yarn while the out sheath of staple fibers provide physical properties to yarn surface [12].

Friction spinning system can produce a wide range of composite yarns with core-sheath concept, through selective blend options of diverse materials in the core and sheath with linear density of $\mathrm{Ne} 1 \mathrm{~s}$ to $18 \mathrm{~s}$, having transfer speeds up to $300 \mathrm{~m} / \mathrm{min}$ [13].

H.W. Krausa, H.A. Soliman and H. Stalder also provide a detail study to explain the yarn manufacturing process in friction spinning [14]. Nathaniel H. Kolmes developed composite yarns from single glass fiber strand with linear density of yarn denier ranging from about 1800 to about 5000 . This yarn provided the flexibility to knit along with good cut and abrasion resistance properties [15-16].

Another study from Jeffery W. Simons, Hyung-Seop Shin, Donald A. Shockey, and David C. Erlich elaborates the cut resistance of some yarns manufactured form high performance fibers like Spectra, Kevlar and Zylon [17]. This was done under shear-tension loading mechanism by penetrating a blade like knife in transverse direction of yarns at a constant rate while each yarn was firmly held from both ends in jaws [10]. It was found that the strain to initiate a cut and total energy required to cut are highly affected by the blade sharpness, yarn tension between both jaws and finally the slicing angle. It was observed that Zylon has superior cut resistance in contrast to Kevlar and Spectra at all combinations of above three parameters.

Ramesh Kumar used a blend of polyester and viscose fibers with 70:30 blend ratio as a sheath element and 36 drawn polyester filaments of 150 denier as core components of a composite yarn. It was concluded that the composite yarn is more even along with high modulus in comparison to simply friction spun yarn [18].
There is a study to diverse types of para-aramid fibers classified on their origin; Virgin Kevlar fibers, $2^{\text {nd }}$ grade Kevlar fibers and recycled Kevlar fibers. It is observed that cut resistance is same for all three because of the similar transverse characteristics of fibers and fibrils generated on the surface of yarns during regeneration process which play key role in cut resistance property of knitted fabric. The abrasion resistance test exhibits that virgin Kevlar fibers lose $10 \%, 2^{\text {nd }}$ grade fibers lose $12 \%$ and recycled Kevlar lose $40 \%$ weight in $1^{\text {st }} 1 \mathrm{k}$ cycles of abrasion resistance. But recycled fibers provide cost benefit [19].

\section{MATERIALS \& METHODS}

E-glass, nylon and polyester are used to produce composite yarns with different blend ratios.

E-glass is the most inexpensive glass fiber and is used when high electrical resistance and strength are the key requirements. Glass fiber has a more specific resistance compared to steel.

Silica, $\mathrm{SiO}_{2}$, is the major constituent of glass, but variable volumes of dissimilar metal oxides are also involved in configurations for diverse usages. Silica forms an amorphous network upon solidification, thus capturing metal atoms. Glass fiber softens at temperature around $800^{\circ} \mathrm{C}[7,20]$.

The chemical forces inside the amorphous inorganic glass play key role in its high modulus of $70-80 \mathrm{GPa}$ (table 1). This high value of modulus is the primary reason for the use of glass filament in the manufacturing high performance composite yarns.

\begin{tabular}{|c|c|}
\hline \multicolumn{2}{|c|}{$\begin{array}{l}\text { MECHANICAL PROPERTIES OF THE USED GLASS } \\
\text { CORE }\end{array}$} \\
\hline Parameter & Value \\
\hline Filament Denier & 100 \\
\hline No. of filaments per yarn & 212 \\
\hline Twist (TPI) & 1.05 \\
\hline Tensile strength (GPa) & 5.96 \\
\hline Tensile modulus (GPa) & 76 \\
\hline Density $\left(\mathrm{g} / \mathrm{cm}^{3}\right)$ & 2.58 \\
\hline Elongation at break (\%) & 4.85 \\
\hline
\end{tabular}

Glass is brittle in nature due to which it can't be used as a yarn in textile, predominantly it is not possible to knit gloves where yarn undergoes numerous turns and twists during knitting process. When it is used in core in composite yarns, glass provides brilliant performance results. And now it is being used in manufacturing of knit gloves and fabrics for cut resistant and flame-retardant applications.

Nylon is one of the most broadly used synthetic fiber with reasonable tensile strength and very good abrasion resistance. The latter one makes it a good material for safety gloves. The properties of nylon staple fibers used for this study are presented in table 2 .

Polyester is most widely used synthetic fiber with unique properties of low cost, moderate tensile 
Table 2

PROPERTIES OF USED NYLON STAPLE FIBERS

\begin{tabular}{|l|c|}
\hline \multicolumn{1}{|c|}{ Parameter } & Value \\
\hline Tenacity (g/den) & 8.6 \\
\hline Fineness (den) & 2.6 \\
\hline Staple length (mm) & 50 \\
\hline Moisture regain (\%) & 4 \\
\hline Elongation $(\%)$ & 15 \\
\hline Density $\left(\mathrm{g} / \mathrm{cm}^{3}\right)$ & 1.14 \\
\hline
\end{tabular}

strength, good abrasion resistance in textured form and has broad chemical resistance. It is also available in various forms, types and classifications. But polyester has low melting and glass transition temperature and it is prone to burning risk. But in form of various bends with other fibers it is good for controlling the cost of a composite yarn. Cost benefit is the major objective of study and polyester will play important role in it. The properties of polyester staple fibers used for this study are presented in table 3.

Table 3

PROPERTIES OF USED POLYESTER STAPLE FIBER

\begin{tabular}{|l|c|}
\hline \multicolumn{1}{|c|}{ Parameter } & Value \\
\hline Tenacity (g/den) & 6.8 \\
\hline Fineness (den) & 1.2 \\
\hline Staple length $(\mathrm{mm})$ & 50 \\
\hline Moisture regain $(\%)$ & 0.4 \\
\hline Elongation $(\%)$ & 22 \\
\hline Density $\left(\mathrm{g} / \mathrm{cm}^{3}\right)$ & 1.37 \\
\hline
\end{tabular}

\section{Equipment}

Spinning preparatory process blow room, card and draw frame are utilized for sheath materials. This sheath was then combined with core material the glass fiber at friction spinning machine to produce composite yarns.

Lakshmi Fine Opener consisting of manual feed mechanism with a spiked beater of $320 \mathrm{~mm}$, diameter revolving at $750 \mathrm{rpm}$ with production rate of 220 $\mathrm{kg} / \mathrm{h}$ was utilized at blow room. Carding process consisted of Lakshmi LC363 card machine with chute feed system directly connected with blow room line. Reiter RSB-D40 was utilized as drawing frame with auto-leveler and capable to process stable fibers in the range 22-62 $\mathrm{mm}$.

Dref-3000 friction spinning machine having six spindles have been utilized for composite yarn manufacturing through friction spinning. This machine is capable to produce core spun yarns at delivery speed of $300 \mathrm{~m} / \mathrm{min}$. Yarn is directly wound onto the cone package of $1.5 \mathrm{~kg}$.

Shima Seiki SFG-I flat knitting machine was used to produce knitted gloves. It is the latest automatic seamless gloves manufacturing machine with original sinker system, durable needle bed and lubrication system. $180 \mathrm{rpm}$ speed is utilized for fingers while $105 \mathrm{rpm}$ at palm knitting stage.

Fingers of the glove are knitted in a tubular style, with different lengths as per fitting to human hands. The connection point between the fingers is critical because there are the chances of hole between the fingers. To overcome this issue and link fingers with palm and on another cross linking of loops is done at the edges of fingers. Thumb finger is knitted at the end of all fingers and palm knitting as no needles are free to make it before. The joining of palm and thumb finger is done by split transfer in knitted tubular row. Then the palm of glove is shaped from both edges to narrow down to fit a human hand or wrist It is done by sequential tapering of the tubular knitted fabric by transporting some loops inside the fabric through the two needle beds. The rows between the two tapering activities, the steps involved in transfer toward the inside of the fabric and the number of transferred stitches effect the narrowing process of glove at knitting machine. These are the critical factors to control. Testing of gloves has been done at following equipment:

- Abrasion Resistance testing under ASTM D496698 done at Martindale abrasion tester.

- USTER Tensorapid for testing of tensile strengths of yarns.

- Coup test utilized for testing of cut resistance as per EN 388-2003.

- Air Permeability test performed as per EN 9237.

\section{Methods}

Two sheaths of polyester and nylon were prepared for the manufacturing of core spun yarn to be used in manufacturing of knit gloves. The physical and mechanical properties of these yarns and gloves were analyzed to compare the impact of varying sheath material.

To prepare the sheath material for the composite yarn, Polyester fibers were fed to the Lakshmi Fine Opener after manual opening of fibers revolving at $750 \mathrm{rpm}$ under $55 \%$ relative humidity and $29^{\circ} \mathrm{C}$ temperature.

Opened fibers form a batt at the chute feed mechanism just before the carding machine and evenly fed to the taker-in zone of Lakshmi LC363 carding machine. Critical carding machine settings involve taker-in speeds revolving at 700, 1100 and 1500 rpm respectively, distance between feed plate and taker-in which was 0.05 inch, speeds of cylinder and top set operating at $500 \mathrm{rpm}$ and $4.5 \mathrm{inch} / \mathrm{min}$ respectively, the gauge between top-set and cylinder set to 0.009 inch at front and 0.013 inch at back. Carding was done at $57 \%$ relative humidity and $28^{\circ} \mathrm{C}$ temperature at production rate of $22.5 \mathrm{~kg} / \mathrm{h}$ at $90 \mathrm{~m} / \mathrm{min}$ delivery speed with $93 \%$ efficiency.

The 62 grains/yd carded was fed at Toyoda Breaker Draw Frame to produce 60 grains/yd drawn sliver at $280 \mathrm{~m} / \mathrm{min}$ delivery speed at $80 \%$. This drawn sliver 
was then fed to another finisher draw frame Reiter RSB-D40 operating at $320 \mathrm{~m} / \mathrm{min}$ with $85 \%$ efficiency. Similar process is used for both Nylon and Polyester Sheaths.

Six slivers were fed to the opening zone of the friction spinning machine to form the sheath around the core of glass fiber. The opening zone was incorporated with a carding drum have a tooth wire structure. One core sliver was passed through the drafting zone to form the bottom cover over core filament. Both core and sheath slivers form the sheath portion of composite yarn.

E-glass filaments were fed from below to form the core of composite yarn. E-glass filaments of 100 denier were used to make the count of 75 tex at $62 \%$ $\mathrm{RH}$ and $27^{\circ} \mathrm{C}$. Yarns are then coded for better understanding in subsequent testing. Polyester with glass core named as PG and Nylon with glass core named as NG Assigned Coding is given in table 4.

Table 4

\begin{tabular}{|c|c|c|}
\hline \multicolumn{3}{|c|}{ CODING } \\
\hline Sample identity & $\begin{array}{c}\text { Linear density } \\
\text { (tex) }\end{array}$ & Core denier \\
\hline PG & 74 & 100 \\
\hline NG & 74 & 100 \\
\hline
\end{tabular}

Delivery and spinning speeds were optimized to achieve the final composite yarn count while the opening zone speed was kept constant for all specimens. Only sheath material proportions were changed to adjust the final yarn linear density.

Each composite yarn was used to manufacture six pairs of glove samples on gloves knitting machine. Each glove was made by feeding two ends of a composite yarn at the same time. Yarn feeding rate and courses per inch (CPI) were kept constant for each sample made from each composite yarn to ensure all the parameters at gloves stage do not change.

For each composite yarn fed to the knitting machine, feed rate and CPI were kept same irrespective of change of sheath material. Production details of making gloves from Polyester/Coolmax, Nylon/Coolmax as sheath and Glass as core are described in table 5.

\section{TESTING}

\section{Yarn samples}

Breaking force, elongation at break, breaking time and tenacity are assessed for yarn samples at standard atmosphere conditions of $22^{\circ} \mathrm{C}$ temperature and $65 \%$ relative humidity.

\section{Glove samples}

Gram per sq. Meter mass (GSM) of gloves was measured by cutting two square inch fabric from each glove and then weighed to calculate GSM by given formula:

$$
\text { GSM }=\text { Weight in grams } \times 775
$$

\begin{tabular}{|c|c|c|c|c|}
\hline \multicolumn{5}{|c|}{ Table 5 } \\
\hline $\begin{array}{c}\text { Pample } \\
\text { identity }\end{array}$ & $\begin{array}{c}\text { Glove specs } \\
\text { length } \times \text { width } \\
(\mathbf{m m})\end{array}$ & $\begin{array}{c}\text { End } \\
\text { points }\end{array}$ & WPI/CPI & GSM \\
\hline PG & $240 \times 100$ & 2 & $7 / 7$ & 295 \\
\hline & $240 \times 100$ & 2 & $7 / 7$ & 297 \\
\hline & $240 \times 100$ & 2 & $7 / 7$ & 296 \\
\hline & $240 \times 100$ & 2 & $7 / 7$ & 295 \\
\hline & $240 \times 100$ & 2 & $7 / 7$ & 298 \\
\hline & $240 \times 100$ & 2 & $7 / 7$ & 295 \\
\hline NG & $240 \times 100$ & 2 & $7 / 7$ & 290 \\
\hline & $240 \times 100$ & 2 & $7 / 7$ & 292 \\
\hline & $240 \times 100$ & 2 & $7 / 7$ & 292 \\
\hline & $240 \times 100$ & 2 & $7 / 7$ & 292 \\
\hline & $240 \times 100$ & 2 & $7 / 7$ & 291 \\
\hline & $240 \times 100$ & 2 & $7 / 7$ & 292 \\
\hline
\end{tabular}

Cut resistance and air permeability tests were performed as per standards.

\section{RESULTS}

Yarns

A significant change has been observed in mechanical properties of composite yarns with change in sheath material. These mechanical properties along with yarn coefficient of variation are listed in table 6 .

Table 6

\begin{tabular}{|c|c|c|c|c|c|}
\hline \multicolumn{6}{|c|}{ YARN MECHANICAL PROPERTIES } \\
\hline $\begin{array}{c}\text { Yarn sample } \\
\text { code }\end{array}$ & $\begin{array}{c}\text { Breaking } \\
\text { force } \\
\text { (cN) }\end{array}$ & $\begin{array}{c}\text { CV } \\
(\%)\end{array}$ & $\begin{array}{c}\text { Tenacity } \\
(\mathrm{cN} / \text { tex })\end{array}$ & $\begin{array}{c}\text { CV } \\
(\%)\end{array}$ & $\begin{array}{c}\text { Elongation } \\
\text { at break } \\
(\%)\end{array}$ \\
\hline PG & 821.6 & 4.61 & 11.29 & 4.75 & 2.61 \\
\hline NG & 725.7 & 11.28 & 9.78 & 12.01 & 2.35 \\
\hline
\end{tabular}

Table shows the comparative analysis of elongation at break of both the composite yarns (GCP \& GCN) obtained by changing the sheath type.

Analysis shows significant change in breaking force while changing sheath type from Nylon to Polyester due to the greater tensile strength of Polyester than Nylon.

Effect of changing sheath type on tenacity is not significant for composite yarns because yarn tenacity is mostly dependent on core material type and size.

\section{Gloves}

Abrasion resistance tested at Martindale abrasion tester in accordance with ASTM D4966-98 shown below results (table 7 ).

Cut resistance measured by coup test in accordance with EN 9237 shows below results (table 8).

For both the gloves made from both the composite yarns, good air permeability was achieved. GCN 


\begin{tabular}{|c|c|c|c|c|c|c|}
\hline \multicolumn{7}{|c|}{ TESTED ABRASION RESISTANCE } \\
\hline \multirow{2}{*}{$\begin{array}{c}\text { Sample } \\
\text { code }\end{array}$} & \multicolumn{5}{|c|}{ Abrasion resistance cycles } & \multirow{2}{*}{$\begin{array}{c}\text { Level } \\
\text { achieved }\end{array}$} \\
\hline & $1^{\text {st }}$ & $2^{\text {nd }}$ & $3^{\text {rd }}$ & $4^{\text {th }}$ & Avg. & \\
\hline PG & $2.2 \mathrm{k}$ & $2.2 \mathrm{k}$ & $2.3 \mathrm{k}$ & $2.2 \mathrm{k}$ & $2.2 \mathrm{k}$ & 3 \\
\hline NG & $2.6 \mathrm{k}$ & $2.7 \mathrm{k}$ & $2.7 \mathrm{k}$ & $2.6 \mathrm{k}$ & $2.6 \mathrm{k}$ & 3 \\
\hline
\end{tabular}

Table 8

\begin{tabular}{|c|c|c|c|c|c|c|}
\hline \multicolumn{7}{|c|}{ TESTED CUT RESISTANCE } \\
\hline \multirow{2}{*}{$\begin{array}{c}\text { Sample } \\
\text { code }\end{array}$} & $1^{\text {st }}$ & $2^{\text {nd }}$ & $3^{\text {rd }}$ & $4^{\text {th }}$ & Avg. & $\begin{array}{c}\text { Performance } \\
\text { level }\end{array}$ \\
\hline PG & 9.23 & 9.86 & 9.76 & 9.98 & 9.7 & 3 \\
\hline NG & 9.39 & 7.92 & 8.41 & 9.78 & 8.87 & 3 \\
\hline
\end{tabular}

gloves, made by using Nylon in sheath with Coolmax, show better air permeability performance as compared to GCP made by using Polyester in sheath with Coolmax.

Table 9

\begin{tabular}{|c|c|c|c|c|}
\hline \multicolumn{5}{|c|}{ TESTED AIR PERMEABILITY } \\
\hline \multirow{2}{*}{$\begin{array}{c}\text { Sample } \\
\text { Code }\end{array}$} & \multicolumn{2}{|c|}{ Face (mm/s) } & \multicolumn{2}{c|}{ Back (mm/s) } \\
\cline { 2 - 5 } & 1 & 2 & 1 & 2 \\
\hline PG & 259 & 269 & 269 & 247 \\
\hline NG & 356 & 383 & 367 & 358 \\
\hline
\end{tabular}

New developed gloves are very beneficial regarding cost in mid-range applications in contrast to aramid and steel core gloves. Values for aramids and steel core gloves are taken as per market average sale price for comparison with the cost of new product.

Table 10

\begin{tabular}{|c|c|c|}
\hline \multicolumn{3}{|c|}{ COST BENEFIT ANALYSIS INDICATORS } \\
\hline Glove type & $\begin{array}{c}\text { Development } \\
\text { cost }\end{array}$ & $\begin{array}{c}\text { Cost benefit } \\
(\%)\end{array}$ \\
\hline Steel core & $70 \$$ & 0 \\
\hline Aramids & $58 \$$ & 18 \\
\hline PG/NG & $34 \$$ & 51 \\
\hline
\end{tabular}

\section{CONCLUSION}

It is concluded that the newly developed cut resistance gloves are inexpensive and user friendly with achievement of Level 3 in cut resistance. In view of cost benefit analysis, it is obvious that almost $50 \%$ cost is saved in this product in contrast to steel core and aramid based cut resistant gloves of same levels. No doubt, this product may not perform up to the mark where the requirement is cut level 5 but up to the level 3 , this will compete with its costly counterparts. Cost benefit analysis has also helped to conclude and compare the outcomes with more clarity. It is also recommended to use some other cellulosebased fiber blends with glass core to improve comfort properties along with functional performance level.

\section{REFERENCES}

[1] Clark, L.J.Jr., Clark, D., Process for manufacturing of work gloves, 1980

[2] Boardman, A., Greenberg, D., Vining, A., Weimer, D., Cost-Benefit Analysis (4th Edition), Pearson, 2010

[3] Stainless steel mesh gloves, www.grainger.com, 09 November 2013. [Online]. Available: http://www.grainger.com/ product/HONEYWELL-Cut-Resistance-Gloves-WP89472/_N-mlaZlzOr4b3?s_pp=false. [Accessed 22 March 2016]

[4] Vu Thi, B.N., Vu-Khanh, T., Lara, J., Effect of friction on cut resistance of polymers, In: Journal of Thermoplastic Composite Materials, 2005, 18, 23-35

[5] Kotharia, V.K., Das, A., Sreedevi, R., Cut resistance of textile fabrics - A theoretical and an experimental approach, In: Indian Journal of Fibers \& Textile Research, 2007, 32, 306-311

[6] Kassam, M., Navrozally, A., Jaffer, A., Foamed polymer and its use in the manufacture of gloves, Patent EP patent 2, 243, 802, 2010

[7] Hearle, J., High Performance Fibers, Textile Institute, 2011

[8] Muhammad A., Ali, S.A., Baig, S.A., Mohsin, B., Amjad, F., Rizwan, S., Innovation is creating competitive advantage: a perspective to improve the organic textile products for business growth, In: Industria Textila, 2019, 70, 2, 147-153, http://doi.org/10.35530/IT.070.02.1644

[9] Ansellpro.com, The importance of hand protection, Ansellpro, 06 July 2013. [Online]. Available: http://www.ansellpro. com/product-catalog/. [Accessed 27 March 2016]

[10] Azeem, M., Boughattas, A., Siddique, H.F., Havelka, A., Hussain, S., Comfort properties of nano-filament polyester fabrics: sensory evaluation, In: Industria Textila, 2018, 69, 1, 3-10, http://doi.org/10.35530/IT.069.01.1440

[11] Lord, P., Handbook of Yarn Production: Technology, Science and Economics, Woodhead Publishing, 2003

[12] Nield, R., Ali, A.R.A., Open-End-Spun Core-Spun Yarns, In: Journal of the Textile Institute, 1977, 68, 223-229

[13] Lawrence, C.A., Fundamentals of Spun Yarn Technology, Taylor \& Francis, 2010

[14] Krause, H.W., Soliman, H.A., The Yarn Formation in Friction Spinning, In: International Textile Bulletin: Yarn Forming, 1989, 4, 31-42

[15] Kolmes, N.H., Composite yarn with fiberglass core, Patent EP Patent 1,021,602, 2004

[16] Muhammad, M., Li, N.-W., Muhammad, S.A., Muhammad, K.M., Investigation of various factors affecting the coefficient of friction of yarn by using Taguchi method, In: Industria Textila, 2019, 70, 3, 211-215, http://doi.org/10.35530/IT.070.03.1555

[17] Shin, S., et all, Cut resistance of high-strength yarns, In: Textile Research Journal, 2006, 76, 607-613 
[18] Rameshkumar, C., Anandkumar, P., Kavinmurugan, P., Manojkumar, B., Anbumani, N., Influence of Core Component on the properties of Friction Spun Yarns, In: AUTEX Research Journal, 2008, 8, 106-110

[19] Flambard, X., Vermeulen, B., Ferreira, M., Mechanical and thermal behaviors of first choice, second choice and recycled p-aramid fibers, In: Journal of Textile and Apparel, Technology and Management, 2004, 4, 1

[20] Zia-Ur-Rehman, M., Baig, S.A., Abrar, M., Hashim, M., Amjad, F., Baig, I.A., Usman, M., The impact of intellectual capital, organizational capabilities and innovation on firm performance of textile sector: a moderating effect of GSP Plus, In: Industria Textila, 2019, 70, 6, 572-578, http://doi.org/10.35530/IT.070.06.1632

Authors:

SOBIA NASEEM ${ }^{1}$, GAO LEI FU¹, MUHAMAD MOHSIN², MUHAMMAD SOHAIL AUNJAM ${ }^{3}$, MUHAMMAD ZEESHAN RAFIQ ${ }^{2}$, KHAILD JAMIL ${ }^{4}$, SHAZIA SALAMAT²

${ }^{1}$ Liaoning Technical University, Institute for Optimization and Decision Analytics, 123000, Fuxin, China e-mail: Sobiasalamat4@gmail.com, gaoleifu@163.com

${ }^{2}$ Liaoning Technical University, College of Business Administration, 125105, Xingcheng, China e-mail: mohsinlatifntu@gmail.com, khudian@gmail.com, salamatshazia@yahoo.com

${ }^{3}$ Officer Knitting, Textile Engineer \&amp; Researcher at Interloop Ltd. Texlan Center Pvt. Ltd. Sir Lanka e-mail: sohail.ad@yandex.com

${ }^{4}$ North China Electric Power University, Beijing, China e-mail: khalidjamil29@yahoo.com

Corresponding author:

SOBIA NASEEM

e-mail: Sobiasalamat4@gmail.com 